\title{
METODE PEMBELAJARAN THINK-PAIR-SHARE, KECERDASAN KINESTETIK, DAN PENINGKATAN KETERAMPILAN MOTORIK SENI TARI DI SMP MUHAMMADIYAH 3 DEPOK
}

\author{
Rinanti Murdianing Sunyar dan Kuswarsantyo \\ Program Pascasarjana, Universitas Negeri Yogyakarta \\ E-mail: rinantimurdianingsunyar@gmail.com
}

\begin{abstract}
Abstrak
Penelitian eksperimen ini bertujuan mengetahui perbedaan efektivitas penerapan metode pembelajaran Think-Pair-Share dan metode imitasi dengan kecerdasan kinestetik yang dimiliki oleh masing-masing peserta didik terhadap peningkatan ketrampilan motorik pada mata pelajaran seni tari di SMP Muhammadiyah 3 Depok. Pendekatan yang digunakan dalam penelitian ini adalah kuantitatif, eksperimental-semu dengan teknik analisis data yang digunakan teknik analisis two way anova. Hasil penelitian ini menunjukkan bahwa: (1) hipotesis pertama yang berbunyi "adanya perbedaan yang signifikan pada keefektifan metode Think-Pair-Share dibandingkan dengan metode imitasi jika ditinjau dari peningkatan ketrampilan motorik peserta didik pada mata pelajaran seni tari di SMP Muhammadiyah 3 Depok" teruji kebenarannya dengan nilai $F_{\text {hitung }}$ sebesar 8.086 (2) hipotesis kedua yang berbunyi "adanya perbedaan yang signifikan pada kecerdasan kinestetik yang dimiliki masing-masing peserta didik terhadap ketrampilan motoriknya pada mata pelajaran seni tari di SMP Muhammadiyah 3 Depok" teruji kebenarannya dengan nilai $\mathrm{F}_{\text {hitumg }}$ sebesar 13.148 dan (3) hipotesis ketiga yang berbunyi "adanya perbedaan yang signifikan pada penerapan metode pembelajaran Think-Pair-Share dan kecerdasan kinestetik yang dimiliki oleh masing-masing peserta didik terhadap peningkatan ketrampilan motorik pada mata pelajaran seni tari di SMP Muhammadiyah 3 Depok" diterima secara empiris dengan nilai $\mathrm{F}_{\text {hitung }}$ sebesar 4.242.
\end{abstract}

Kata kunci: Think-Pair-Share, kecerdasan kinestetik, ketrampilan motorik, seni tari

\section{THINK-PAIR-SHARE LEARNING METHOD, KINESTHETIC INTELLIGENCE, AND MOTOR SKILLS IMPROVEMENT OF DANCE LESSONS AT SMP MUHAMMADIYAH 3 DEPOK}

\begin{abstract}
This experiment research aims to know the effectiveness of the implementation of Think-PairShare learning method and imitation method and kinesthetic intelligence that belongs to each of the student in the improvement of motor skills in the subject of dance art in SMP Muhammadiyah 3 Depok. The approach used in this research is the quantitative, quasi experimental design. The data collection instruments used in this research were questionnaires and tests. Data analysis techniques used in this research were descriptive statistic and analysis technique of two way anova. This experiment research shows that: (1) the first hypothesis which says "there are significant differences on the effectiveness of Think-Pair-Share method compared with imitation method reviewed from the improvement of students motor skills in the subject of dance art in SMP Muhammadiyah 3 Depok" is accepted with an $\mathrm{F}_{\text {count }} 8.086,(2)$ the second hypothesis which says "there is a significant differences in the kinesthetic intelligence that belongs to each of the student toward the motor skills in the subject of dance art in SMP Muhammadiyah 3 Depok" is accepted with $\mathrm{F}_{\text {count }} 13.148$, and (3) the third hypothesis saying "there is a significant difference in the implementation of
\end{abstract}


Think-Pair-Share learning method and kinesthetic intelligence that belong to each of the student in the improvement of motor skills in the subject of dance art in SMP Muhammadiyah 3 Depok" is empirically accepted with the $\mathrm{F}_{\text {count }}$ of 4.242 .

Keywords: Think-Pair-Share, kinesthetic intelligence, motor skills, dance art

\section{PENDAHULUAN}

Banyaknya metode yang bermunculan diharapkan guru akan semakin inovatif dalam setiap kegiatan belajar mengajar agar siswa tidak hanya menjadi pendengar namun juga dapat menjadi partisipan dalam proses pembelajaran. Keadaan tersebut berbeda dengan apa yang dialami oleh guru Seni Budaya terutama mata pelajaran seni tari karena sampai saat ini dalam pembelajaran seni tari mayoritas guru seni tari masih menggunakan metode yang konvensional seperti metode imitasi, demonstrasi, dan ceramah. Sayangnya, hingga saat ini metodemetode tersebut masih dianggap paling ampuh untuk mengajarkan seni tari pada siswa. Salah satunya juga terjadi di SMP Muhammadiyah 3 Depok dalam kegiatan belajar mengajar untuk mata pelajaran Seni Budaya terutama seni tari juga masih menggunakan metode konvensional. Seni tari merupakan salah satu mata mata pelajaran yang lebih menekankan pada skill (keterampilan) sehingga pada mata pelajaran ini kemampuan psikomotor siswa lebih diutamakan walaupun sebenarnya baik kemampuan kognitif maupun afektif juga turut berperan dalam mata pelajaran seni tari.

Penelitian ini bermaksud untuk melakukan eksperimen dengan membandingkan antara metode imitasi dengan metode Think-Pair-Share variabel bebas kedua kecerdasan kinestetik yang dimiliki masing-masing peserta didik jika ditinjau dari peningkatan kemampuan ketrampilan motorik peserta didik dalam menari di SMP Muhammadiyah 3 Depok sebab dalam pada penelitian ini peserta didik diminta untuk menganalisis sebuah ragam gerak sehingga ketrampilan gerak dalam mencari dan menemukan gerak yang benar sesuai dance script lebih ditekankan.

\section{Belajar dan Pembelajaran}

Menurut Biggs belajar dicirikan oleh suatu perubahan yang bertahan lama oleh individu dan tidak diwariskan. Hampir senada dengan Morgan, Cronbach (dalam Suprijono, 2013: 2) mendefinisikan belajar sebagai "learning is shown by a change in behavior as a result of experience", yaitu belajar merupakan perubahan perilaku sebagai hasil dari pengalaman. Bloom menjelaskan jika hasil belajar meliputi kemampuan kognitif, afektif, dan psikomotor. Perubahan akibat belajar cenderung bertahan lama dan bahkan sampai taraf tertentu. Kemampuan yang diperoleh menjadi milik pribadi sehingga hal apapun yang menjadi hasil dari belajar akan membekas pada diri individu sedangkan menurut Winkel (1991: 52) belajar adalah kegiatan mental yang tidak dapat disaksikan dari luar sehingga orang lain tidak bisa mengetahuinya hanya dengan mengamati. Beberapa teori belajar dari tokohtokoh pemrakarsa teori behaviorisme dan kognitivisme sangat berpengaruh dan berkaitan erat dengan pembahasan penelitian ini yang berhubungan dengan pembelajaran ketrampilan motorik.

Beberapa pengertian di atas dapat disimpulkan jika belajar adalah perubahan tingkah laku dan mental individu melalui sebuah proses panjang dan bukan diwariskan sehingga cenderung mampu bertahan lama yang merupakan hasil dari pengalaman. Hasil belajar yang diperoleh meliputi kemampuan kognitif, afektif, dan psikomotor tidak akan tampak hanya dengan mengamati namun hal tersebut akan tampak ketika seseorang itu menampakkan kemampuan yang telah diperoleh.

Pembelajaran merupakan proses interaksi peserta didik dengan pendidik dan sumber belajar yang bertujuan untuk membantu peserta didik agar dapat belajar dengan baik. Proses 
pembelajaran manusia dialami sepanjang hayat, di manapun dan kapan pun. Pembelajaran merupakan pekerjaan yang komplek karena diperlukan perencanaan dan pertimbangan yang bijaksana. Lingkungan pembelajaran pun harus disiapkan supaya kondusif sehingga peserta didik mampu menerima pelajaran dengan baik.

Seperti yang telah dijelaskan jika belajar dan pembelajaran merupakan dua hal yang berkaitan erat. Bukan belajar jika tidak ada proses pembelajaran, dan tidak akan ada proses pembelajaran jika manusia tidak ingin belajar. Begitu pun dalam belajar seni tari, proses pembelajaran yang baik dengan didukung lingkungan yang kondusif memiliki peran yang sangat besar pada hasil akhir pembelajarannya. Bukan hanya manusianya yang perlu diperhatikan namun dari sarana prasana yang mendukung juga perlu diperhatikan dan disiapkan karena dalam pembelajaran seni khususnya seni tari membutuhkan sarana dan prasana yang sangat memadai seperti ruang yang cukup luas agar peserta didik dapat bergerak dengan bebas, nyaman dan tidak berdesak-desakan, alat pengeras suara (speaker) yang digunakan untuk mengiringi peserta didik dalam menari, media, maupun properti tari. Ketersediaan hal-hal tersebut mampu memberikan kontribusi bagi keberhasilan proses pembelajaran seni tari.

\section{Pembelajaran Kooperatif}

Pembelajaran kooperatif adalah salah satu bentuk pembelajaran yang berdasarkan paham konstruktivis. Pemikiran para filsafat konstruktivisme tentang hakikat pengetahuan memberikan sumbangan terhadap mendekonstruksi pembelajaran. Pengetahuan itu dikonstruksikan, bukan dipersepsi secara langsung oleh indra. Tidak peduli bagaimana pengetahuan didefinisikan, terbentuk di dalam otak manusia, dan subjek yang berpikir tidak memiliki alternatif selain mengonstruksikan apa yang diketahui berdasarkan pada pengalamannya sendiri, sehingga bersifat subjektif (Suprijono, 2013: 29-30). Menurut Slavin (dalam Isjoni, 1985: 15) pembelajaran kooperatif ialah suatu model pembelajaran menekankan siswa belajar dan bekerja dalam kelompok-kelompok kecil secara kolaboratif yang anggotanya 4-6 dengan struktur kelompok heterogen. Berdasarkan pendapat-pendapat di atas dapat disimpulkan bahwa pembelajaran kooperatif adalah suatu metode pembelajaran dimana di dalam prosesnya mewujudkan kegiatan belajar mengajar yang berpusat kepada peserta didik dengan cara berkelompok. Pembelajaran kooperatif bukan menekankan kepada persaingan namun pada bagaimana bekerjasama dan saling menghargai antar siswa sehingga pembelajaran kooperatif adalah cara mengajar dengan berbasis peace education. Pembelajaran kooperatif sangat cocok jika dikaitkan dengan pembelajaran seni, sebab pembelajaran seni mengarah pada pembentukan rasa kemanusiaan (Pamadhi, 2012: 13).

\section{Metode Pembelajaran Think-Pair-Share dan Metode Imitasi}

Dalam pembelajaran kooperatif terdapat beberapa metode pembelajaran yang dapat diterapkan salah satunya ialah Think-PairShare. Metode ini dikembangkan oleh Frank Lyman dan Spencer Kagan. Seperti namanya "Thinking" yang artinya pada setiap dimulainya pembelajaran guru mengawali dengan mengajukan pertanyaan untuk dipikirkan oleh peserta didik. Lalu kata "Pairing" yang memiliki pengertian pada tahap ini guru meminta peserta didik berpasang-pasangan untuk berdiskusi tentang pertanyaan yang diberikan oleh guru. Selanjutnya "Sharing" pada tahap ini diharapkan terjadi tanya jawab yang mendorong pada pengkonstruksian pengetahuan secara integratif.

Menurut Ledlow (2001: 1) menjelaskan jika Think-Pair-Share merupakan sebuah solusi sederhana untuk masalah pemberdayaan peserta didik dalam proses belajar mengajar. Think-PairShare merupakan salah satu strategi berisiko rendah untuk mendapatkan banyak siswa aktif dalam berbagai ukuran kelas. Think-Pair-Share adalah strategi pembelajaran kooperatif dimana peserta didik berpikir tentang tanggapan dari pertanyaan kemudian mendiskusikan bersama pasangan masing-masing. Think-Pair-Share 
memiliki keunggulan seperti optimalisasi partisipasi siswa dengan memberikan delapan kali lebih banyak pada setiap siswa untuk dikenali dan menunjukkan partisipasi mereka kepada orang lain.

Metode pembelajaran yang kedua ialah metode imitasi. Dalam Kamus Besar Bahasa Indonesia imitasi berarti tiruan. Metode imitasi atau peniruan adalah sebuah metode penyampaian tari secara tradisional yang banyak dipergunakan guru-guru tari tertama di perkumpulan-perkumpulan tari. Dalam pelaksanaannya guru biasanya mengajarkan bentuk secara keseluruhan yang diselingi koreksi terhadap gerakan peserta didik yang dianggap salah. Metode ini sering pula disebut dengan "sistem imam" dimana peserta didik diusahakan untuk meniru sepenuhnya apa yang dilakukan oleh gurunya (Abdurachman, 1979: 78). Adapun kekurangan metode imitasi adalah hanya sekedar meniru sehingga tidak ada pemahaman dan berpikir kreatif di dalam prosesnya sehingga menjadikan peserta didik cenderung pasif. Sikap pasif memberikan dampak yang kurang bagus pada perkembangan peserta didik seperti kurangnya kepercayaan diri, cenderung individualistis, dan tidak mampu mengungkapkan pendapat untuk saling berdiskusi. Untuk itulah diperlukan metode pembelajaran baru yang lebih aktif dan mampu memberdayakan siswa baik secara pikiran maupun sosial. Berdasarkan penjelasan di atas, diharapkan dengan menerapkan metode pembelajaran Think-Pair-Share dapat memberikan solusi baru untuk pelajaran Seni Budaya khususnya seni tari sehingga peserta didik dapat diberdayakan secara maksimal dan mampu memberikan manfaat positif baik dari kualitas hasil belajar dengan mendapatkan pengalaman secara langsung maupun sikap sosial yang dihasilkan dari penerapan ThinkPair-Share.

\section{Kecerdasan Kinestetik}

Kecerdasan kinestetik ialah kecerdasan yang berhubungan dengan jasmani atau badan. Orang yang memiliki kecerdasan ini memroses informasi melalui sensasi yang dirasakan pada badan. (Jasmine, 2012: 25). Kecerdasan kinestetik merupakan salah satu hal penting yang harus dimiliki dalam mempelajari seni tari. Peserta didik yang memiliki bakat dalam menari sudah tentu memiliki kecerdasan kinestetik yang baik sebab dalam menari yang akan menjadi medianya ialah tubuh penari itu sendiri sehingga jika seorang penari tidak memiliki koordinasi, keseimbangan, kekuatan, fleksibilitas, maupun kecepatan yang baik maka akan sangat sulit untuk mempelajari sebuah tarian. Terkait hal tersebut maka seberapa baik penguasaan tarian pada peserta didik juga tergantung tinggi rendahnya kecerdasan kinestetik yang dimiliki. Hasil dari penelitian Sutapa (2014: 154) membuktikan bahwa kebermanfaatan model pembelajaran pendidikan jasmani berbasis kinestetik dapat digunakan untuk menstimulasi pengembangan kecerdasan majemuk peserta didik usia prasekolah.

\section{Keterampilan Motorik}

Motorik (gerak) manusia tidak terlepas dari ilmu gerak, kinesiologi, performance manusia, pendidikan jasmani, dan body movement. Tujuan pembelajaran motorik adalah sebuah upaya mengubah perilaku motorik melalui kondisi dan situasi yang sengaja diciptakan agar proses perubahan menjadi efektif dan efisien Belajar ketrampilan motorik menuntut kemampuan untuk merangkai sejumlah gerak-gerik jasmani menjadi suatu keseluruhan yang dilakukan dengan gencar dan luwes tanpa perlu memikirkan lagi secara mendetail apa yang dilakukan dan alasan dilakukannya gerakan tersebut (Winkel, 199, 104). Hasil belajar peserta didik pada penelitian ini akan lebih ditinjau dari aspek wiraga. Pada dasarnya wiraga erat hubungannya dengan cara menilai bnetuk fisik tari terutama segi geraknya, adapun ketrampilan gerak penari diukur dengan ketentuan (indeks nilai) yang telah ditetapkan. (Jazuli, 1994: 119).

\section{Hipotesis}

Adapun hipotesis penelitian dalam penelitian ini adalah (1) Adanya perbedaan yang signifikan pada keefektifan metode Think-Pair-Share dibandingkan dengan metode imitasi jika 
ditinjau dari peningkatan ketrampilan motorik peserta didik pada mata pelajaran seni tari di SMP Muhammadiyah 3 Depok, (2) adanya perbedaan yang signifikan pada kecerdasan kinestetik yang dimiliki masing-masing peserta didik terhadap ketrampilan motoriknya pada mata pelajaran seni tari di SMP Muhammadiyah 3 Depok, dan (3) adanya perbedaan yang signifikan pada penerapan metode pembelajaran Think-Pair-Share dan kecerdasan kinestetik yang dimiliki oleh masing-masing peserta didik terhadap peningkatan ketrampilan motorik pada mata pelajaran seni tari di SMP Muhammadiyah 3 Depok.

\section{METODE}

\section{Jenis Penelitian}

Penelitian ini menggunakan pendekatan kuantitatif berupa studi penelitian eksperimental semu. Dalam penelitian ini yang menjadi variabel bebas adalah metode pembelajaran $\left(\mathrm{X}_{1}\right)$ dan kecerdasan kinestetik $\left(\mathrm{X}_{2}\right)$, sedangkan variabel terikatnya ialah ketrampilan motorik (Y).

\begin{tabular}{|cccc|}
\hline & Pre-test & Treatment & Post-test \\
$\mathrm{Kk}$ & $\mathrm{T}_{1 \mathrm{e}}$ & $\mathrm{X}$ & $\mathrm{T}_{2 \mathrm{e}}$ \\
$\mathrm{Kk}$ & $\mathrm{T}_{1 \mathrm{c}}$ & & $\mathrm{T}_{2 \mathrm{c}}$ \\
\hline
\end{tabular}

Gambar 1. Paradigma Penelitian

\footnotetext{
Keterangan :

$\mathrm{T}_{1 \mathrm{e}}$ : Kelompok eksperimen yang diberikan prestest

$\mathrm{T}_{1 \mathrm{c}}$ : Kelompok kontrol yang diberikan pre-test

$\mathrm{T}_{2 \mathrm{e}}$ : Kelompok eksperimen yang diberikan post-test

$\mathrm{T}_{2 \mathrm{c}}^{2 \mathrm{e}}$ : Kelompok kontrol yang diberikan post-test

$\mathrm{Kk}$ : Kecerdasan kinestetik

$\mathrm{X}$ : Treatment
}

\section{Waktu dan Tempat Penelitian}

Penelitan ini dilaksanakan pada bulan September hingga Desember 2016 di SMP Muhammadiyah 3 Depok. Alasan dilaksanakannya penelitian ini di sekolah tersebut dikarenakan belum pernah diadakan penelitian mengenai metode pembelajaran Think-Pair-Share terutama pada mata pelajaran seni tari.

\section{Subjek Penelitian}

Pada penelitian ini yang akan menjadi subjek penelitian adalah peserta didik kelas VIII. Adapun populasi dari penelitian ini ialah seluruh peserta didik kelas VIII di SMP Muhammadiyah 3 Depok. Teknik sampling yang dipergunakan ialah simple random sampling.

\section{Instrumen dan Teknik Pengumpulan Data}

Pada penelitian ini teknik pengumpulan data yang digunakan adalah observasi, kuesioner, dan tes. Instrumen yang digunakan untuk melakukan observasi ialah menggunakan lembar obsevasi, Pada pengukuran kecerdasan kinestetik diukur oleh peneliti sedangkan pada pengukuran ketrampilan motorik diukur oleh tiga orang tim ahli. Pengukuran kecerdasan kinestetik menggunakan instrumen persepsi kinestetik (Kinestetic Obstacle Test) oleh Barry L. Johnson and Jack K. Nelson, 1986. Kuesioner yang berupa angket terbuka dalam penelitian ini digunakan untuk menjaring respon peserta didik setelah diberikan treatment dengan metode Think-Pair-Share.

\section{Teknik Analisis Data}

Dalam penelitian ini teknik analisis data menggunakan statistik deskriptif yang digunakan untuk menyajikan mean, median, modus dan standar deviasi. Selain menggunakan teknik statistik deskriptif dalam penelitian ini juga menggunakan teknik two way anova. Pada penelitian ini pula menggunakan uji prasyarat analisis berupa uji normalitas dan uji homogenitas.

\section{HASIL DAN PEMBAHASAN Gambaran Umum SMP Muhammadiyah 3 Depok}

SMP Muhammadiyah 3 Depok melaksanakan program fullday school yakni dengan menerapkan One Day in School yang dimulai dari pukul 07.15 dan diakhiri pukul 15.30. SMP Muhammadiyah 3 Depok bertempat di jalan Rajawali 10, Demangan Baru, Caturtunggal, Depok, Sleman. SMP Muhammadiyah 3 Depok merupakan salah satu sekolah yang menerapkan kurikulum 
Tabel 1. Hasil Uji Normalitas

\begin{tabular}{clccc}
\hline No & \multicolumn{1}{c}{ Ketrampilan motorik } & $\mathbf{Z}_{\text {score }}$ & Sig & Ket \\
\hline 1 & Pre-test Think-Pair-Share & 0,790 & 0,561 & Normal \\
2 & Post-test Think-Pair-Share & 0,619 & 0,838 & Normal \\
3 & Kinestetik-Think-Pair-Share & 0,932 & 0,350 & Normal \\
4 & Pre-test Imitasi & 0,581 & 0,889 & Normal \\
5 & Post-test Imitasi & 0,814 & 0,521 & Normal \\
6 & Kinestetik-Imitasi & 1,090 & 0,186 & Normal \\
\hline
\end{tabular}

Sumber : Data Primer 2017

Tabel 2. Hasil Uji Homogenitas

\begin{tabular}{clccc}
\hline \multicolumn{2}{c}{ Ketrampilan motorik } & $\boldsymbol{F}$ & Sig & Ket \\
\hline Pre-test & $\begin{array}{l}\text { Think-Pair-Share } \\
\text { Imitasi }\end{array}$ & 1,914 & 0,183 & Homogen \\
\hline Post-test & $\begin{array}{l}\text { Think-Pair-Share } \\
\text { Imitasi }\end{array}$ & 0,053 & 0,821 & Homogen \\
\hline
\end{tabular}

Sumber : Data Primer 2017

KTSP dimana di dalam proses pembelajaran mata pelajaran Seni Budaya dibagi menjadi tiga bidang yakni seni rupa, seni musik, dan seni tari. Proses belajar mengajar untuk mata pelajaran Seni Budaya khususnya seni tari guru masih menggunakan metode pembelajaran konvensional yang menjadikan siswa cenderung pasif dan kurang percaya diri untuk memberikan pendapat atau bahkan mengajukan pertanyaan. Guru mendemonstrasikan ragam gerak yang akan dipelajari dan peserta didik mengimitasi gerak yang ditampilkan oleh guru. Proses pembelajaran seperti telah berlangsung sejak bertahun-tahun yang lalu. Hal tersebut terjadi karena banyak faktor, selain keterbatasan guru dan fasilitas yang ada dapat juga disebabkan oleh kurang siapnya siswa untuk meningkatkan kualitas belajar mereka sehingga perlu adanya pendekatan berbeda.

\section{Hasil Analisis Data}

Hasil analisis data bertujuan untuk mengetahui gambaran data hasil penelitian ini. Hasil analisis data disajikan berdasarkan nilai minimum, maksimum, standar deviasi, dan nilai rata-rata. Berdasarkan hasil deskriptif diperoleh nilai minimum ketrampilan motorik siswa yang menggunakan metode ThinkPair-Share sebelum dilakukannya perlakuan yaitu 27,00 dan paling tinggi 38,33. Rata-rata ketrampilan motorik siswa pada metode ini yaitu 32,20. Kelas dengan metode pembelajaran imitasi diperoleh nilai minimum yaitu 23,33 dan paling tinggi 40,33 . Nilai rata-rata pada metode ini yaitu 30,94. Secara umum, diperoleh ketrampilan motorik siswa baik pada metode Think-Pair-Share maupun imitasi memiliki nilai ketrampilan motorik siswa yang masih rendah. Berikut adalah hasil deskriptif yang merupakan data ketrampilan motorik peserta didik pada metode Think-Pair-Share dan imitasi.

\section{Uji Hipotesis dan Pembahasan}

Analisis yang digunakan untuk mengetahui tujuan penelitian ini yaitu analisis uji two way anova. Hasil uji two way anova dapat dilihat pada tabel 4.

\section{Perbedaan keefektifan metode Think- Pair-Share dibandingkan dengan metode imitasi jika ditinjau dari peningkatan ketrampilan motorik peserta didik pada mata pelajaran seni tari di SMP Muhammadiyah 3 Depok}

Berdasarkan hasil two way anova dapat diketahui bahwa terdapat perbedaan yang signifikan ketrampilan motorik seni budaya siswa khususnya seni tari antara siswa yang menggunakan metode Think-Pair-Share dan 
Tabel 3. Hasil Analisis Data Belajar Siswa

\begin{tabular}{lcccccc}
\hline \multicolumn{1}{c}{ Deskriptif } & $\begin{array}{c}\text { Pre-test } \\
\text { TPS }\end{array}$ & $\begin{array}{c}\text { Post-test } \\
\text { TPS }\end{array}$ & $\begin{array}{c}\text { Kinestetik } \\
\text { TPS }\end{array}$ & $\begin{array}{c}\text { Pre-test } \\
\text { Imitasi }\end{array}$ & $\begin{array}{c}\text { Post-test } \\
\text { Imitasi }\end{array}$ & $\begin{array}{c}\text { Kinestetik } \\
\text { Imitasi }\end{array}$ \\
\hline Mean & 32,20 & 41,63 & 85,50 & 30,94 & 36,82 & 71,36 \\
Median & 30,83 & 41,33 & 90,00 & 30,33 & 37,33 & 80,00 \\
Mode & 38,33 & 36,00 & 90,00 & 30,33 & 37,33 & 80,00 \\
Std. Deviation & 4,23 & 3,50 & 20,61 & 6,27 & 4,02 & 17,19 \\
Variance & 17,90 & 12,23 & 424,72 & 39,26 & 16,13 & 295,46 \\
Minimum & 27,00 & 36,00 & 30,00 & 23,33 & 27,33 & 40,00 \\
Maximum & 38,33 & 47,33 & 100,00 & 40,33 & 41,67 & 90,00 \\
Sum & 321,98 & 416,33 & 855,00 & 340,33 & 404,98 & 785,00 \\
\hline
\end{tabular}

Sumber : Data Primer 2017

Tabel 4. Hasil Uji Two Way Anova

\begin{tabular}{|c|c|c|c|c|c|}
\hline \multicolumn{2}{|c|}{ Ketrampilan motorik } & \multirow{3}{*}{$\begin{array}{c}\text { Rerata } \\
41,63 \\
36,82\end{array}$} & \multirow{3}{*}{$\begin{array}{l}\mathbf{F}_{\text {hitung }} \\
8,086\end{array}$} & \multirow{3}{*}{$\begin{array}{c}\text { Signifikansi } \\
0,012\end{array}$} & \multirow{3}{*}{$\begin{array}{c}\text { Keterangan } \\
\text { Signifikan }\end{array}$} \\
\hline Metode & Think-Pair-Share & & & & \\
\hline & Imitasi & & & & \\
\hline \multirow{3}{*}{$\begin{array}{c}\text { Kecerdasan } \\
\text { Kinestetik }\end{array}$} & Kurang & 33,17 & \multirow{3}{*}{13,148} & \multirow{3}{*}{0,001} & \multirow{3}{*}{ Signifikan } \\
\hline & Rata-rata & 36,46 & & & \\
\hline & Sempurna & 42,12 & & & \\
\hline Metode * Kecerdasa & & & 4,242 & 0,035 & Signifikan \\
\hline
\end{tabular}

Sumber : Data Primer 2017

metode imitasi dengan nilai $\mathrm{F}_{\text {hitumg }}$ sebesar 8,086 dan nilai signifikansi sebesar 0,012 yang lebih kecil dari 0,05 . Kesimpulannya bahwa terdapat perbedaan yang nyata ketrampilan motorik siswa pada kedua kelompok dengan metode yang berbeda sehingga hipotesis pertama dalam penelitian ini yang menyatakan bahwa "Adanya perbedaan yang signifikan pada keefektifan metode Think-Pair-Share dibandingkan dengan metode imitasi jika ditinjau dari peningkatan ketrampilan motorik peserta didik pada mata pelajaran seni tari di SMP Muhammadiyah 3 Depok" diterima.

Pada angket terbuka yang ditujukan untuk peserta didik yang diberikan perlakuan menggunakan metode Think-Pair-Share mayoritas memberikan respon positif terhadap penggunaan metode tersebut meskipun masih ada beberapa peserta didik yang lebih senang jika menggunakan metode imitasi. Peserta didik merasakan pengalaman belajar tari yang baru dengan metode ini, salah satunya mereka harus berpikir lebih keras dan harus berkonsentrasi, selain itu peserta didik dapat merasakan bagaimana rasanya ketika mereka harus mengajarkan sebuah tarian kepada temannya sendiri sehingga mereka harus memiliki pemahaman yang lebih pada ragam gerak yang akan mereka ajarkan dan harus pula memiliki keberanian untuk menyampaikannya di depan kelas.

2. Perbedaan kecerdasan kinestetik yang dimiliki masing-masing peserta didik terhadap ketrampilan motoriknya pada mata pelajaran seni tari di SMP Muhammadiyah 3 Depok

Hasil pada tabel di atas juga menunjukkan bahwa terdapat perbedaan yang signifikan kecerdasan kinestetik siswa terhadap ketrampilan motorik seni tari. Hal ini ditunjukkan dengan nilai $F_{\text {hitung }}$ sebesar 13,148 dan nilai signifikansi sebesar 0,001 yang lebih kecil dari 0,05. Kesimpulannya hipotesis kedua dalam penelitian ini yang menyatakan "Adanya perbedaan yang signifikan pada kecerdasan kinestetik yang dimiliki masing-masing peserta didik terhadap ketrampilan motoriknya pada mata pelajaran 
seni tari di SMP Muhammadiyah 3 Depok “ diterima oleh hasil penelitian empiris.

Pada hasil penelitian ini terdapat data yang menunjukkan jika anak yang memiliki kecerdasan kinestetik pada kategori kurang juga mampu mendapatkan hasil yang cukup meningkat dari nilai pre-test dan post-test-nya. Meski demikian, berdasarkan hasil analisis uji hipotesis yang signifikan membuktikan jika kecerdasan kinestetik yang dimiliki oleh masing-masing anak memang memberikan pengaruh pada prestasi belajar tarinya yang dalam hal ini lebih ditinjau pada ketrampilan motorik tarinya.

\section{Efektivitas penerapan metode} pembelajaran Think-Pair-Share dan kecerdasan kinestetik yang dimiliki oleh masing-masing peserta didik terhadap peningkatan ketrampilan motorik pada mata pelajaran seni tari di SMP Muhammadiyah 3 Depok

Hasil interaksi antara metode dan kecerdasan kinestetik menunjukkan hasil yang signifikan dengan nilai $\mathrm{F}_{\text {hitung }}$ sebesar 4,242 dan nilai signifikansi sebesar 0,035 yang berarti bahwa ada perbedaan yang signifikan ketrampilan motorik siswa dengan menggunakan metode Think-Pair-Share dan imitasi yang diikuti dengan kecerdasan kinestetik. Dengan demikian hipotesis dalam penelitian ini yang menyatakan bahwa adanya perbedaan yang signifikan pada penerapan metode pembelajaran Think-PairShare dan kecerdasan kinestetik yang dimiliki oleh masing-masing peserta didik terhadap peningkatan ketrampilan motorik pada mata pelajaran seni tari di SMP Muhammadiyah 3 Depok diterima.

Diharapkan dengan metode Think-PairShare dapat berguna dan lebih menguntungkan peserta didik dalam belajar seni tari sehingga mampu meningkatkan kualitas ketrampilan motoriknya dalam menari. Hal ini sesuai dengan pendapat yang dikemukakan oleh Sousa (2012:250) ketrampilan yang dikembangkan oleh seni adalah kreativitas, pemecahan masalah, berpikir kritis, komunikasi, kemandirian, inisiatif, dan kolaborasi atau kerjasama yang nantinya akan diperlukan oleh setia peserta didik untuk bertahan hidup dan mencapai keberhasilan di masa dewasa.

Pada hasil interaksi menunjukkan bahwa metode dan kemampuan kinestetik berpengaruh pada ketrampilan motorik peserta didik. Pada metode imitasi, peserta didik yang memiliki kemampuan kinestetik dalam hal menari cenderung hanya mengikuti gerakan yang sudah diajarkan tanpa ada peran aktif dari peserta didik. Hal ini menyebabkan kemampuan yang dimiliki pesera didik tidak tereksplor lebih mendalam. Oleh karena itu, ketrampilan motoriknya juga tidak berkembang ataupun tidak maksimal. Sedangkan pada metode Think-Pair-Share peserta didik dilibatkan dalam kegiatan pembelajaran sehingga kemampuan kinestetik peserta didik menjadi lebih dengan menggunakan metode pembelajaran tersebut. Hal ini mampu meningkatkan ketrampilan motorik peserta didik karena peran dari metode pembelajaran dan kemampuan kinestetik yang dimiliki siswa.

\section{KESIMPULAN}

Hasil penelitian yang telah dilakukan mengenai ketrampilan motorik seni tari di SMP Muhammadiyah 3 Depok, maka dapat diambil tiga kesimpulan sebagai berikut;

\section{Perbedaan keefektifan metode Think- Pair-Share dibandingkan dengan metode imitasi jika ditinjau dari peningkatan ketrampilan motorik peserta didik pada mata pelajaran seni tari di SMP Muhammadiyah 3 Depok}

Berdasarkan hasil two way anova diketahui bahwa terdapat perbedaan yang signifikan ketrampilan motorik seni tari peserta didik antara peserta didik yang menggunakan metode Think-Pair-Share dan metode imitasi dengan nilai $\mathrm{F}_{\text {hitung }}$ sebesar 8,086 dan nilai signifikansi sebesar 0,012 yang lebih kecil dari 0,05 sehingga hipotesis pertama dalam penelitian ini yang menyatakan bahwa "Adanya perbedaan yang signifikan pada keefektifan metode Think-PairShare dibandingkan dengan metode imitasi jika ditinjau dari peningkatan ketrampilan motorik 
peserta didik pada mata pelajaran seni tari di SMP Muhammadiyah 3 Depok" diterima.

Hal tersebut membuktikan bahwa metode pembelajaran Think-Pair-Share memberikan pengaruh positif baik dalam kemampuan akademik maupun sosial khususnya pada mata pelajaran seni tari. Think-Pair-Share memberikan kesempatan bagi peserta didik untuk mengeksplor perbendaharaan gerak yang dimiliki melalui proses menganalisa danceskript tari. Think-Pair-Share juga memberikan pengalaman baru bagi peserta didik untuk berani menyampaikan bahkan mengajarkan ragam gerak tari pada teman-temannya.

2. Perbedaan kecerdasan kinestetik yang dimiliki masing-masing peserta didik terhadap ketrampilan motoriknya pada mata pelajaran seni tari di SMP Muhammadiyah 3 Depok

Pada hasil penelitian ini menunjukkan terdapat perbedaan yang signifikan kecerdasan kinestetik siswa terhadap ketrampilan motorik seni tari. Hal ini ditunjukkan dengan dengan nilai $\mathrm{F}_{\text {hitung }}$ sebesar 13,148 dan nilai signifikansi sebesar 0,001 yang lebih kecil dari 0,05. Dengan demikian hipotesis kedua dalam penelitian ini yang menyatakan "Adanya perbedaan yang signifikan pada kecerdasan kinestetik yang dimiliki masing-masing peserta didik terhadap ketrampilan motoriknya pada mata pelajaran seni tari di SMP Muhammadiyah 3 Depok “ diterima oleh hasil penelitian empiris.

3. Efektivitas penerapan metode pembelajaran Think-Pair-Share dan kecerdasan kinestetik yang dimiliki oleh masing-masing peserta didik terhadap peningkatan ketrampilan motorik pada mata pelajaran seni tari di SMP Muhammadiyah 3 Depok

Berdasarkan hasil uji two way anova juga menunjukkan adanya interaksi antara metode dan kecerdasan kinestetik dengan nilai $\mathrm{F}_{\text {hitung }}$ sebesar 4,242 dan nilai signifikansi sebesar 0,035. Dengan demikian hipotesis dalam penelitian ini yang menyatakan bahwa adanya perbedaan yang signifikan pada penerapan metode pembelajaran
Think-Pair-Share dan kecerdasan kinestetik yang dimiliki oleh masing-masing peserta didik terhadap peningkatan ketrampilan motorik pada mata pelajaran seni tari di SMP Muhammadiyah 3 Depok diterima.

Metode pembelajaran Think-Pair-Share terbukti memberikan inovasi baru dan pengaruh pada peningkatan ketrampilan motorik menari peserta didik yang tentunya didukung pula dengan kecerdasan kinestetik yang dimiliki masing-masing anak. Pengoptimalan keterlibatan peserta didik dalam proses belajar megajar adalah hal yang sangat penting dan dapat membantu peserta didik lebih paham dengan apa yang mereka pelajari. Anak belajar untuk menganalisis sebuah ragam gerak sehingga mampu membantu mengeksplorasi kemampuan anak yang terkait dengan menari sehingga tidak hanya sekedar meniru dan menghafal sebab pada masa remaja intelegensi mereka dapat dioptimalkan penuh jika tidak hanya mendapat dukungan dari orang-orang terdekat namun juga perlu penanganan yang tepat sehingga dapat dimanfaatkan untuk mencapai prestasi-prestasi akademik maupun non-akademik.

\section{DAFTAR PUSTAKA}

Abdurachman, Rosid dan Iyus Rusliana. (1979). Pendidikan Kesenian Seni Tari III. Jakarta: C.V Angkasa

Isjoni. (2013). Pembelajaran Kooperatif Meningkatkan Kecerdasan Komunikasi Antar Peserta Didik. Yogyakarta: Pustaka Pelajar.

Jasmine, Julia. (2012). Metode Mengajar Multiple Intelligences. Bandung: Nuansa Cendekia.

Jazuli, M. (1994). Telaah Teoritis Seni Tari. Semarang: IKIP Semarang Press.

Johnson, Barry L and Jack K.Nelson. (1986). Practical Measurements For Evaluation In Physical Education-Fourth Edition. New York:Macmillan Publising Company.

Ledlow, Susan. (2001). Using Think-Pair-Share in the Collage Classroom. Arizona State University, 1.

Pamadhi, Hajar. (2012). Pendidikan Seni Hakikat, Kurikulum Pendidikan Seni, 
Habitus Seni dan Pengajaran Seni untuk Anak. Yogyakarta: UNY Press.

Suprijono, Agus. (2013). Cooperative Learning Teori dan Aplikasi PAIKEM. Yogyakarta: Pustaka Pelajar.

Sutapa, Panggung, Sukardiyanto dan BM. Wara Kushartanti. (2014). Pengembangan Model Pembelajaran Pendidikan Jasmani
Berbasis Kinestetik untuk Anak Usia Pra Sekolah. Universitas Negeri Yogyakarta, 2, 154 .

Sousa, David A.(2012). Bagaimana Otak Belajar Edisi Keempat. Jakarta Barat: PT Indeks.

Winkel, W.S. (1991). Psikologi Pengajaran. Jakarta: PT Gramedia. 